CORRECTION

\title{
Correction: Recoding of stop codons expands the metabolic potential of two novel Asgardarchaeota
}

Jiarui Sun (D), Paul N. Evans (DD, Emma J. Gagen (iD, Ben J. Woodcroft (iD, Brian P. Hedlund (iD, Tanja Woyke (iD, Philip Hugenholtz (iD and Christian Rinke (iD)

(c) The Author(s) 2022

ISME Communications; https://doi.org/10.1038/s43705-021-00048-6

Correction to: ISME Communications https://doi.org/10.1038/s43705021-00032-0, published online 28 June 2021

The original version of this article unfortunately contained mistakes. There was a mix-up among the ORCIDs and the corresponding authors

The original article has been corrected.

\begin{abstract}
(c) (1) Open Access This article is licensed under a Creative Commons Attribution 4.0 International License, which permits use, sharing adaptation, distribution and reproduction in any medium or format, as long as you give appropriate credit to the original author(s) and the source, provide a link to the Creative Commons license, and indicate if changes were made. The images or other third party material in this article are included in the article's Creative Commons license, unless indicated otherwise in a credit line to the material. If material is not included in the article's Creative Commons license and your intended use is not permitted by statutory regulation or exceeds the permitted use, you will need to obtain permission directly from the copyright holder. To view a copy of this license, visit http://creativecommons. org/licenses/by/4.0/.
\end{abstract}

() The Author(s) 2022 